\title{
Gereja di Rumah: Kontekstualisasi Fungsi-fungsi Rumah dalam Masa Perjanjian Baru untuk Pekabaran Injil
}

\author{
Djeffry Hidajat* \\ *Penulis adalah dosen penuh waktu di Sekolah Tinggi Teologi Cipanas. \\ Email: djeffry.hidajat@yahoo.com
}

\begin{abstract}
Abstrak: Gereja dalam Perjanjian Baru adalah gereja di rumah. Mengapa murid-murid Yesus dan Paulus menggunakan rumah untuk kegiatan gereja? Mereka menggunakan rumah karena rumah adalah unit sosial, ekonomi dan religius. Ibadah dan pengajaran rohani biasa diadakan dalam rumah-rumah pada waktu itu. Karena fungsi sosial dan ekonominya, rumah juga membuka kontak dan komunikasi bagi para penginjil untuk memberitakan tentang Injil Yesus Kristus kepada jaringan sosial rumah di mana mereka melayani. Dengan demikian murid-murid Yesus dan Paulus telah melakukan upaya kontekstual yang cerdas dengan menggunakan rumah untuk membangun komunitas Kristen sekaligus pekabaran Injil. Terbukti kekristenan diterima secara luas dengan pendekatan gereja di rumah ini di tiga abad pertama sejarah kekristenan.
\end{abstract}

Kata-kata kunci: Kontekstualisasi, Gereja Rumah, Oikos, Komunitas Kristen, Pekabaran Injil

Abstract: The churches in New Testament times met together within houses. Why did Jesus' disciples and Paul utilize the house for the church's activities? They did so because the house was the foundational unit pertaining to the social, economic and religious structures of society. The house was a common place that could be used for worship and religious teaching. Moreover, because of the social and economic functions of the household, the house provided a sphere of easy interaction and communication with others in order to evangelize them with the Gospel of Jesus Christ. Thus, the disciples and Paul are facilitating contextualized structures in their use of the house unit for the building of Christian community and evangelization. This effectiveness can be evidenced by the wide acceptance of Christianity throughout the first three centuries of Christianity.

Keywords: Contextualization, House Church, Oikos, Christian Community, Evangelism 


\section{Pendahuluan}

Dalam Perjanjian Baru, gereja adalah gereja rumah. Di dalam rumah orang-orang berkumpul untuk beribadah dan berkomunitas. Ketika menuliskan teologia Paulus tentang gereja rumah, Branick menulis: “. . . the household with its family setting was the church. Out that household arose some of the earliest offices and structures that would shape the course of the church through the centuries." Menurut Flemming, Paulus menggunakan sejumlah aspek budaya Helenistik seperti bahasa dan gambaran-gambaran, retorika dan juga institusi dan kebiasaan dalam budaya. ${ }^{2}$ Dalam hal institusi budaya, Paulus menggunakan hal mendasar dalam kehidupan sosial dunia Helenistik, yaitu rumah tangga. ${ }^{3}$ Upaya kontekstualisasi Paulus mempunyai tujuan, yang dalam perkataan Flemming: "Surely his ultimate concern was not whether a particular expression or idea was Jewish or Greek in its origin, but whether it could be used in service of the gospel and mission of Jesus Christ." ${ }^{4}$ Artikel ini akan menyampaikan kontekstualisasi institusi budaya, yaitu rumah yang bertujuan untuk pekabaran Injil.

\section{Penggunaan Kata "Rumah" dalam Perjanjian Baru}

Kata "rumah" dalam Alkitab banyak digunakan. Baik dalam pengertian harfiah maupun metafora. Untuk itu dalam awal artikel ini akan diuraikan secara singkat survei kata "rumah" dalam Perjanjian Baru. Bahasa Yunani untuk "rumah" adalah oikos atau oikia. Banyaknya penggunaan oikos dan oikia menunjukkan bahwa penulisan teks-teks Perjanjian Baru mempunyai latar belakang para pembaca jemaat gereja rumah.

\footnotetext{
${ }^{1}$ Vincent Branick, The House Church in the Writings of Paul (Wilmington, Michael Glazier, 1989), 13.

${ }^{2}$ Dean Flemming, Contextualization in the New Testament: Pattern for Theology and Mission. Downers Grove: IVP, 2005), 126-134.

${ }^{3}$ Ibid., 133.

${ }^{4}$ Ibid., 134.
}

Dalam TDNT oikos lebih dimengerti sebagai tempat yaitu rumah dan tempat tinggal. ${ }^{5}$ Oikia dalam Perjanjian Baru dapat berarti rumah, keluarga atau rumah tangga. ${ }^{6}$ TDNT menuliskan bahwa sering kali oikos merujuk pada sebuah tempat ibadah. Dalam Perjanjian Lama oikos merupakan kata favorit karena digunakan juga dalam arti keluarga dan ras serta metafora rumah Allah yang nantinya berpengaruh dalam Perjanjian Baru. Dalam hal ini oikos-lah yang biasanya dikaitkan dengan rumah Allah, bukan oikia. Dalam Perjanjian Lama, Musa adalah pelayan setia dalam rumah Tuhan (Ibr. 3:1-6) tetapi Kristus sebagai Anak adalah berkuasa atas rumah Allah $(3: 2,6 ; 10: 21)$. Dalam Perjanjian Lama rumah-Ku adalah Israel. Jadi rumah Allah berkaitan dengan komunitas. ${ }^{7}$

Menurut EDNT, pada umumnya oikos dan oikia dapat dipakai saling menggantikan. ${ }^{8}$ Walaupun demikian oikos lebih dominan dari oikia dalam PB, yaitu muncul 115 kali. Oikia lebih dominan dalam Markus dan Matius. Berbeda dengan TDNT, EDNT memperlihatkan adanya nuansa arti yang berbeda antara oikos dan oikia: oikos lebih dekat dengan kepunyaan seseorang sedangkan oikia lebih pada tempat tinggal. ${ }^{9}$ Tetapi secara keseluruhan oikos dan oikia dapat ditukarkan penggunaannya. Hal ini misalnya terlihat pada satu nats digunakan kedua kata tanpa membedakan arti. Misalnya dalam Lukas 15:6, 8; 1 Korintus 11:22, 34; juga 1 Korintus 1:16, 16:15 di mana kedua kata berarti keluarga. Dalam Injil Sinoptik, untuk cerita yang sama kata rumah dalam Markus 5:38 menggunakan

${ }^{5}$ Gerhard Kittel, Gerhard Friedrich, eds., Theological Dictionary of the New Testament. Vol. 5. Tr. Geoffrey W. Bromiley (Grand Rapids: Eerdmans, 1967), 119.

${ }^{6} T D N T, 5.130$

${ }^{7}$ Ibid., 125-128.

${ }^{8}$ Horst Balz dan Gerhard Schneider, Exegetical Dictionary of the New Testament. Vol. 2. (Grand Rapids: Eerdmans, 1991), 501.

${ }^{9} E D N T$, 2.501. Juga Collin Brown, ed., New International Dictionary of New Testament Theology. Vol. 2 (Grand Rapids: Zondervan, 1986), 247 menuliskan bahwa pada awalnya ada pembeda seperti demikian tetapi setelah LXX kedua kata menjadi sinonim. 
oikos sedangkan ayat paralelnya Matius 9:23 menggunakan oikia. Markus 3:25 dan Matius 12:25 menggunakan oikia sedangan dalam ayat paralelnya di Lukas 11:17 menggunakan oikos. Matius 24:43 menggunakan oikia sedangkan Lukas 12:39 menggunakan oikos.

Arti yang paling banyak muncul dalam Perjanjian Baru untuk oikia dan oikos adalah dalam arti dasar yaitu rumah, bangunan atau tempat tinggal. ${ }^{10}$ Oikos 46 kali dan oikia 71 kali. Dalam Markus paling banyak dipakai kata oikos atau oikia, yaitu sebanyak 24 kali. Bandingkan dengan Matius yang hanya 11 kali dan Lukas 9 kali untuk ayat-ayat yang berparalel. ${ }^{11}$

Dalam tulisan di TDNT disebutkan bahwa struktur jemaat adalah dalam keluarga, kelompok dan rumah. ${ }^{12}$ Walaupun demikian uraian TDNT itu sebatas menunjukkan bahwa rumah adalah untuk tempat pertemuan dan bersekutu. Kutipan dari NIDNTT berikut dapat dijadikan sebagai kesimpulan dari studi kata di bagian ini: "The formation of the house churches, which can be explained on the basis of the missionary situation, was of the greatest significance for the spreading of the gospel. With them the early church took over the natural order of life, without falling into idealization of the house churches."13

Dalam Kisah Para Rasul dan surat-surat Paulus, rumah selalu menjadi tempat pertemuan pengikut Kristus. Demikian penggunaan rumah untuk pertemuan jemaat di Yerusalem (Kis. 1:13 "ruang di atas"; Kis. 2:41-47). Pelayanan Paulus di berbagai kota selalu di rumah tertentu selain di rumah ibadah. Rumah tempat menumpang ini menjadi semacam titik awal pekabaran Injil di kota-kota yang Paulus layani dan juga tempat pertemuan Paulus dan orang-orang percaya di kota-kota itu. Di Filipi, Paulus menumpang di rumah Lidia (Kis. 16:15-16), rumah Yason di Tesalonika

\footnotetext{
${ }^{10}$ NIDNTT, 2.248 .

${ }^{11} E D N T, 2.501$.

${ }^{12}$ Ibid., 130.

${ }^{13}$ NIDNTT, 2.250 .
}

(Kis. 17:7), rumah Akwila di Korintus (Kis. 18:1), ruang atas di Troas (Kis. 20:8, 11), rumah Filipus di Kaisarea (21:8). Paulus sendiri sering menyebut kumpulan orang percaya dengan sebutan jemaat di rumah-rumah tertentu. Misalnya: jemaat di rumah Priskila dan Akwila (Rm. 16:3-5); rumah Aristobulus (Rm. 16:10), rumah Narkisus (Rm. 16:11), Gayus yang memberi tumpangan (Rm. 16:23), jemaat di rumah Nimfa (Kol. 4:15), Paulus pernah tinggal di rumah Karpus di Troas (2Tim. 4:13).

Mengapa pengajaran Yesus, teks-teks Injil dan surat-surat banyak menggunakan kata rumah dan mengambil kisah dengan latar belakang rumah? Karena gereja saat itu ada di rumah!

\section{Fungsi Rumah pada Masa Perjanjian Baru}

Dari beberapa faktor luar yang menyebabkan terjadinya perluasan kekristenan, Harnack menyebutkan bahwa adanya asosiasi-asosiasi yang berkembang dalam Kerajaan Romawi menjadi lahan diterimanya kekristenan. ${ }^{14}$ Harnack sendiri lebih melihat bahwa organisasi Kristen yang dikembangkan murid-murid dan saudara-saudara Yesus meminjam dari Yudaisme, yaitu sinagoge. ${ }^{15}$ Riset terkini yang sejalan dengan Harnack adalah tulisan Banks $^{16}$ dan Dunn. ${ }^{17}$ Harnack cenderung melihat banyak persamaan antara berkembangnya sinagoge dan gereja.

Para penulis setelah Harnack mempunyai pandangan yang berbeda. Scroggs lebih

${ }^{14}$ Adolf von Harnack, The Expansion of Christianity in the First Three Century. 2 Vols. Tr. James Moffat (Eugene: Wipf \& Stock, 1998), 1.22.

${ }^{15}$ Ibid., 2.47.

${ }^{16}$ Dalam Robert Banks, Paul's Idea of Community. Rev. ed (Peabody: Hendrickson, 1994), 14. Banks berpendapat bahwa pembanding yang paling dekat dengan komunitas yang dibangun Paulus adalah sinagoge dan agama misteri.

\footnotetext{
${ }^{17}$ James D. G. Dunn, Beginning From Jerusalem. Christianity in the Making Volume 2 (Grand Rapids: Eerdmans, 2009), 617-620.
} 
melihatnya sebagai sekte. ${ }^{18}$ Ia menjelaskan dengan pendekatan social-scientific criticism bahwa komunitas Kristen mula-mula adalah sebuah sekte karena bercirikan: dimulai dari sebuah protes, menolak realitas yang diabaikan oleh lembaga yang mapan, egalitarian, menawarkan kasih dan penerimaan dalam kelompoknya, merupakan asosiasi bebas, menuntut komitmen total anggotanya, dan bersifat adventis (menunggu saat akhir).

Malina lebih menjelaskan komunitas Kristen mula-mula sebagai asosiasi sukarela di dunia Mediterania, yaitu kelompok orang karena adanya kepentingan sosial yang sama, yaitu merasakan perlunya perubahan dan untuk mencapai kepuasan secara sosial. ${ }^{19}$ Pilihan lainnya adalah model sekolah filsafat. Ada sejumlah penulis yang memperlihatkan beberapa aspek yang dikembangkan oleh Paulus serupa dengan pola sekolah filsafat. ${ }^{20}$

Pandangan Meeks lebih bersifat mengintegrasi pilihan-pilihan yang ada. Ia menuliskan bahwa ekklesia sebagai komunitas Kristen terbentuk dari perpaduan model-model yang ada di sekitar lingkungan gereja yaitu model rumah tangga, asosiasi sukarela, sinagoge dan sekolah filsafat/retorik. Meeks sendiri memberikan kesimpulan tambahan bahwa tidak ada satu pun model yang menangkap semua nuansa komunitas gereja tetapi ia

${ }^{18}$ Robin Scroggs, "The Earliest Christian Community as Sectarian Movement," dalam David G. Horrel, Social-scientific Approaches to New Testament Interpretation (Edinburgh: T\&T Clark, 1999), 69-91. Juga John Elliott, $A$ Home for the Homeless: A Sociological Exegesis of 1Peter, Its Situation and Strategy (Philadelphia: Fortress, 1981), 102-6.

${ }^{19}$ Bruce J. Malina, "Early Christian Groups: Using Small Group Formation Theory to Explain Christian Organization," dalam Philip F. Esler, Modelling Early Christianity: Social-Scientific Studies of the New Testament in its Context (London: Routledge, 1995), 110, menjelaskan lebih lanjut bahwa pembentukkan kelompok ini terjadi karena mereka berbagi pengalaman dalam kebangkitan Kristus (Mat. 28:18-20; Kis. 1:6-11; Gal. 1:16; 1Kor. $15: 8,3-6)$. Sedangkan perubahan sosial yang diinginkan orang-orang Kristen waktu itu adalah meneruskan misi pengutusan Yesus (Mrk. 6:7-13; Mat. 10:1-11; Luk. 9:1-5). Lihat ibid. 99-101.

${ }^{20}$ Lihat diskusi tentang hal ini dalam Wayne A. Meeks, The First Urban Christian: The Social World of the Apostle Paul (New Haven: Yale University Press, 1983), 81-84. menyatakan bahwa rumah tangga merupakan konteks dasar. ${ }^{21}$ Dengan demikian konteks rumah dan rumah tangga merupakan model utama.

Rumah, yaitu oikos menurut Luhrmann bukan hanya sekadar menjadi konteks dasar dari pertemuan suatu kelompok dalam berbagai jenis kelompok di atas, tetapi:22 "merupakan bentuk dasar sosial dan ekonomi untuk dunia kuno dan Perjanjian Baru dan bahkan untuk semua kehidupan menetap sebelum masa industri." Berikut ini akan diuraikan rumah dalam fungsi ekonomi, sosial seperti yang disebutkan oleh Luhrmann dan akan ditambahkan kemudian dengan fungsi religius seperti yang dipaparkan oleh Gehring untuk memperlihatkan bahwa mengapa rumah menjadi konteks dasar perkembangan kegiatan religius pada umumnya dan kekristenan secara khusus pada masa Perjanjian Baru.

\section{Fungsi Ekonomi Rumah}

Dalam bahasa Yunani kata ekonomi mempunyai kata dasar "rumah". Ekonomi atau oikonomia berarti manajemen rumah atau pengaturan rumah. ${ }^{23}$ Dari kata dasarnya terlihat bahwa rumah dalam budaya Romawi-Yunani dan bahkan pada budaya kuno lainnya merupakan unit dasar ekonomi. Dalam Perjanjian Baru fungsi ekonomi rumah banyak disebutkan khususnya dalam perumpamaan dan pengajaran Yesus. ${ }^{24}$ Yesus menggunakan perumpamaan yang diperankan oleh tuan dan hamba (Mat. 24:45), hal keuangan (Mat. 25:15); diskriminasi terhadap istri dan anakanak (Mat. 18:23-34); buruh upah harian (Mat. 20:1) dan produksi dari rumah (Mat. 21:33-41) dan lain-lain.

${ }^{21}$ Ibid., 84; juga E.A. Judge, The Social Pattern of Christian Groups in the First Century (London: Tyndale, 1960), 36.

${ }^{22}$ Luhrmann, "Neutestamentliche Haustafen," 87 yang dikutip Gehring, House Church and Mission: The Importance of Household Structures in Early Christianity (Peabody: Hendrickson, 2004), 17.

${ }^{23}$ Crosby, House of Disciples: Church, Economics \& Justice in Matthew (Maryknoll: Orbis, 1988), 1.

${ }^{24}$ Judge, The Social Pattern, 30. 
Dalam konteks pedesaan, perekonomian masyarakat bertumpu pada tanah. Tanah merupakan sumber utama dihasilkannya makanan yang menjadi kebutuhan dasar manusia. ${ }^{25}$ Tanah dikelola menghasilkan sayuran, biji-bijian dan tumbuhan lainnya yang dapat dimakan. Pada tanah dipelihara ternak yang menghasilkan susu, daging, wol dan barang-barang lainnya.

Dengan uraian di atas maka masyarakat agrikultural di pedesaan pada umumnya mengaitkan kekayaan dengan tanah. Jika mereka mempunyai kelebihan sumber daya, mereka akan berusaha memiliki tanah lebih banyak lagi. Karena ketika dikelola tanah, akan menghasilkan lebih banyak lagi kekayaan. Kekayaan berupa tanah ini akan diwariskan secara turun-temurun, dan karenanya ekonomi rumah terbentuk dari keluarga. ${ }^{26}$ Anggota keluargalah yang pada mulanya membantu segala pekerjaan mengelola tanah. Mereka yang lebih kaya dengan tanah yang lebih luas mempekerjakan orang lain atau budak untuk mengelola tanahnya. Masing-masing keluarga dalam mengelola tanah menghasilkan barang-barang tertentu yang dikonsumsi sendiri. ${ }^{27}$ Kelebihan produksi mereka kemudian dibarter atau dijual. Biasanya hal ini terjadi di pasar di desanya atau dibawa ke kota untuk dijual di sana. ${ }^{28}$

Dalam konteks perkotaan, interaksi sosial karena faktor ekonomi ini menjadi lebih luas karena pertukaran barang bukan semata barang-barang yang berkaitan dengan makanan. Di perkotaan muncul orang-orang yang ahli membuat barang tertentu misalnya para tukang tembikar, pembuat piring, tukang tenun kain, pandai besi, pembuat barang dari kulit seperti sepatu dan tenda, pematung, pembuat perhiasan dan lain-lain

\footnotetext{
${ }^{25}$ John Stambaugh dan David Balch, Dunia Sosial Kekristenan Mula-mula (Jakarta: BPK Gunung Mulia, 1997), 72.

${ }^{26}$ Crosby, House of Disciples, 23.

${ }^{27}$ David A. deSilva, Honor, Patronage, Kinship \& Purity: Unlocking New Testament Culture (Downers Grove: IVP, 2000), 179
}

${ }^{28}$ Stambaugh, Dunia Sosial, 74. yang biasanya dikerjakan dalam bengkelbengkel mereka sendiri. ${ }^{29}$ Pada umumnya, mereka menjadikan lantai pertama rumah atau bagian muka sebagai bengkel dan atau toko. Sedangkan lantai dua atau bagian belakang rumah sebagai tempat tinggal. Hal ini yang terjadi pada Priskila dan Akwila sebagai tukang kemah, yaitu membuat ataupun menjual kemah dari kulit (Kis. 18:3, 26). Demikian juga ada para penjual jasa seperti pembersih kain, pedagang, ahli hukum, dokter, pemilik penginapan, tukang cukur. Ataupun para pekerja seperti budak, buruh harian dan pekerja tetap yang bekerja untuk para majikan pada rumah tangga tertentu atau tempat usaha tertentu.

Semua kegiatan ekonomi di atas, baik dalam konteks pertanian maupun kota, pada umumnya dilakukan di rumah-rumah dan dari rumah ke rumah. Dengan adanya perdagangan, maka terjadi interaksi antarkeluarga dan sumber-sumbernya sehingga komunitas yang lebih luas menjadi dapat berfungsi. ${ }^{30}$ Itulah sebabnya rumah merupakan unit dasar ekonomi yang membangun komunitas yang lebih luas. ${ }^{31}$

\section{Fungsi Sosial Rumah}

Selain berfungsi secara ekonomis, rumah mempunyai fungsi sosial. Di dalam rumah keluarga-keluarga tinggal. Keluarga dalam rumah jelas merupakan unit sosial terkecil dalam masyarakat. Dalam keluarga terdapat ayah, ibu, anak-anak laki-laki, anakanak perempuan, sering kali berikut anggota keluarga lainnya seperti saudara laki-laki, saudara perempuan, kakek, nenek atau saudara lainnya serta para pembantu, selir dan tamu yang menumpang. ${ }^{32}$ Daftar ini untuk

\footnotetext{
${ }^{29}$ Ibid., 75.

${ }^{30}$ Crosby, House of Disciples, 23.
}

${ }^{31}$ Branick dalam The House Church, 38 dengan mendasarkan pada para penulis kuno seperti Aristoteles dan Plutarch menuliskan bahwa rumah adalah unit dasar politik dan ekonomi dan menjadi landasan bagi komunitas.

${ }^{32}$ Geoffrey W. Bromiley, ed., The International Standard Bible Encyclopedia. 4 vols. Rev. (Grand Rapids: Eerdmans, 1988), 2.280. 
memperlihatkan luasnya cakupan yang disebut keluarga dalam suatu rumah dalam masyarakat kuno. Walaupun demikian pada umumnya keluarga terdiri dari keluarga inti yang terdiri dari ayah, ibu, anak pertama dengan keluarganya dan anak-anak lain yang belum menikah. Keluarga semacam ini menjadi unit sosial, residensial, konsumsi dan produksi yang efektif. ${ }^{33}$

Perjanjian Baru mengindikasikan anggotaanggota keluarga ini, khususnya keluarga inti yaitu suami, istri, anak-anak dan para pekerja dalam rumah. Hal ini terdapat dalam dua house codes (aturan rumah tangga) dalam tulisan-tulisan Paulus, yaitu Efesus 5:21-6:9 dan Kolose 3:18-4:1. ${ }^{34}$ Dalam aturan rumah tangga ini diperlihatkan bagaimana anggotaanggota keluarga menjalankan perannya masing-masing dan berinteraksi satu dengan yang lainnya. Hal ini merupakan pola umum dalam masyarakat kuno karena para filsuf pengikut Aristoteles dan Neo-Pitagoras membahas hal ini. ${ }^{35}$ Demikian juga dapat ditemukan paralelitas dengan tulisan para rabi dan filsuf Stoik. ${ }^{36}$

Dalam keluarga ayah atau suami adalah kepala rumah tangga. ${ }^{37}$ Baik orang Yahudi maupun budaya Romawi-Yunani menganut patriarkalisme, yaitu pria yaitu ayah yang menjadi pemimpin keluarga. Dalam budaya Romawi hal ini dikenal sebagai paterfamilias. Ia digambarkan mempunyai kuasa untuk menentukan mati-hidupnya seorang anak. ${ }^{38}$ Walaupun demikian sebenarnya paterfamilias lebih merupakan pemahaman dari aspek

\footnotetext{
${ }^{33}$ Bruce J. Malina, The New Testament World: Insight from Cultural Anthropology. Rev. ed. (Louisville: Westminster/John Knox), 122.

${ }^{34}$ Di luar tulisan Paulus adalah dalam 1 Petrus 2:13-3:8.

${ }^{35}$ Stambaugh, Dunia Sosial, 148.

${ }^{36} \mathrm{~F}$. F. Bruce, The Epistles to the Colossians, to Philemon, and to the Ephesians. NICNT (Grand Rapids: Eerdmans, 1984), 162.

${ }^{37}$ deSilva, Honor, Patronage, 173.

${ }^{38}$ Branick, The House Church, 37; deSilva, Honor, Patronage, 185.
}

hukum dan kepemilikan. ${ }^{39}$ Ia tidak harus punya istri atau anak untuk menjadi paterfamilias, ia hanya perlu punya barang-barang sebagai hak milik.

Menarik dicatat di sini bahwa walaupun pria menjadi pemimpin, para wanita biasanya menjadi manajer dalam rumah. ${ }^{40}$ Dalam Alkitab hal ini tecermin dalam Amsal 31:1031, 1 Timotius 5:14 dan Titus 2:4-5. Ialah yang mengelola keseharian rumah tangga. Artinya peran wanita cukup banyak dan penting. Wanita juga dapat menjadi pemimpin keluarga. Mereka menjadi materfamilias bukan karena kelahiran atau status pernikahan tetapi karena karakter yang baik dan kesuksesan mereka. Wanita, biasanya para janda, yang mempunyai barang milik seperti budak dan tanah dapat disebut sebagai paterfamilia. Ada contoh-contoh tertulis untuk hal ini dalam literatur Yunani-Romawi. ${ }^{41}$ Demikian juga dalam Perjanjian Baru: ibu dari Yohanes Markus (Kis. 12:12-17), Lidia di Filipi (Kis. 16:14-15, 40), Nimfa (Kol. 4:15).

Anak-anak dipelihara dan dididik dalam keluarga, khususnya oleh ibu dan para budak atau pembantunya. Ayah juga bertanggung jawab untuk pendidikan anak. Pendidikan ini pada umumnya dilakukan di rumah. Mereka yang mempunyai uang akan membayar guru untuk mengajar anak-anak mereka. Anak wanita tetap dalam pengawasan ibunya sampai ia menikah. Dengan demikian anak menjadi "berutang besar" kepada orang tuanya dan karena itu sebagai balasannya mereka wajib menghormati dan taat kepada orang tua. ${ }^{42}$

\footnotetext{
${ }^{39}$ Carolyn Osiek, Margaret Y. MacDonald, dan Janet H. Tulloch, A Woman's Place: House Churches in Earliest Christian (Minneapolis: Fortress, 2006), 154; James S. Jeffers, The Graeco-Roman World of the New Testament Era: Exploring the Background of the Early Christianity (Downers Grove: IVP, 1999), 238.

${ }^{40}$ Branick, The House Church, 50; Meeks, The First Urban Christian, 23. Osiek, et al., A Woman's Place, 145-52 155-6

${ }^{41}$ Osiek, MacDonald, dan Tulloch, A Woman's Place,

${ }^{42}$ deSilva, Honor, Patronage, 186. Menurut Jeffers, The Graeco-Roman World, 248 kebajikan anak semacam ini disebut sebagai pietas, sama seperti seseorang berutang dan menundukkan diri pada dewa tertentu.
} 
Dari sudut pandang orang tua, anak akan menjadi rekan dan pendukung utama orang tua ketika mereka berusia lanjut.

Dalam cakupan yang lebih luas, terjadi juga hubungan antara keluarga dengan keluarga yaitu klan. Pada umumnya klan terbentuk karena pertalian darah atau pernikahan dalam keluarga-keluarga. Hubungan antarkeluarga juga dapat terjadi karena afiliasi politik atau kerjasama ekonomi. Hubungan-hubungan antarkeluarga ini menjadi penting dalam konteks perkembangan kekristenan karena jaringan sosial semacam ini yang memungkinkan Injil disebarluaskan dengan cepat. Dengan adanya jaringan sosial semacam ini para misionaris mendapat kemudahan. Jika ia mendapat tuan rumah yang menampungnya, maka anggota keluarga dan jaringan sosial tuan rumah akan menjadi objek pekabaran Injil.

\section{Fungsi Religius Rumah}

Di samping aspek sosial dan ekonomi, Crosby menunjukkan bahwa rumah adalah sekaligus unit dasar agama dalam masyarakat. ${ }^{43}$ Para istri mengikuti dewa suaminya dan mengajarkannya kepada anak-anaknya. Para budak yang baru dibeli diharapkan mengikuti dewa dari tuannya. Para anggota keluarga beribadah dan minta perlindungan dari dewa keluarganya. Hal ini menjelaskan mengapa dalam Perjanjian Baru terdapat banyak baptisan serumah, misalnya Kornelius (Kis. 10:2; Lidia di Filipi (Kis. 16:15) dan kepala penjara (Kis. 16:33), Keluarga Stefanas di Korintus (1Kor. 1:16; 16:5). Menurut Judge pertobatan serumah bukan hanya alamiah dan diperlukan untuk memantapkan agama baru dalam lingkungan yang belum dikenal, tetapi rumah tangga adalah merupakan fondasi paling masuk akal untuk pertemuan Kristen. ${ }^{44}$ Crosby menyimpulkan bahwa: ${ }^{45}$ upaya memahami arti "gereja" di abad pertama

\footnotetext{
${ }^{43}$ Crosby, House of Disciples, 31-32. Dalam Judge, The Social Pattern, 35 disebutkan bahwa agama adalah salah satu solidaritas dalam rumah tangga.

${ }^{44}$ Judge, The Social Pattern, 36.

${ }^{45}$ Crosby, House of Disciples, 32.
}

tidak mungkin terpisahkan dari rumah tangga (household)."

Fungsi religius rumah tampak ketika orang Kristen mula-mula memilih rumah sebagai tempat bergereja. Menurut Gehring dalam seluruh tulisannya, ${ }^{46}$ fungsi gereja rumah dijelaskan dalam dua aspek, yaitu aspek eklesiologis dan aspek misional. Jika banyak penulis telah memperlihatkan aspek eklesiologis gereja rumah, maka sambil mendukung aspek eklesiologis rumah, Gehring menekankan pula aspek misionalnya. Struktur gereja rumah bagi Gehring penting untuk melakukan pekerjaan misi dan pekabaran Injil.

\section{Kontekstualisasi Rumah untuk Pekabaran Injil}

Rumah yang mempunyai fungsi ekonomi, sosial dan religius merupakan struktur yang ada dalam masyarakat dan telah mengakar lama. Orang Kristen mula-mula menggunakan struktur rumah ini untuk pengembangan pekabaran Injil. Dengan demikian jelas terlihat bahwa para pemimpin dan misionari dalam Gereja Mula-mula telah melaksanakan upaya kontekstualisasi pertama dan cerdas agar Injil dapat diterima oleh masyarakat pada waktu itu.

Hal pertama yang menonjol mengenai penggunaan rumah pada Gereja Mula-mula adalah karena untuk pertumbuhan gereja diperlukan ruang untuk melaksanakan pertemuan. Untuk itu rumahlah yang dipakai. Mereka tidak perlu mengeluarkan biaya untuk membangun rumah ibadah khusus, cukup menyediakan ruang makan atau ruang lainnya untuk pertemuan Kristen. Karena itu gereja di rumah menjadi bangunan gereja yang umum pada masa dua abad pertama. Grant menyebutkan bahwa orang Kristen lambat dalam membangun rumah ibadah khusus juga karena alasan eskatologis, yaitu dirasakan tidak perlu membangun gedung ibadah jika dunia segera berakhir. Alasan teologis ini juga ditambah dengan kesulitan pendanaan

\footnotetext{
${ }^{46}$ Lihat Gehring, House Church and Mission: The Importance of Household Structures in Early Christianity (Peabody: Hendrickson, 2004).
} 
dan status hukum yang belum jelas serta kecenderungan untuk lebih menggunakan dana untuk kebajikan membuat rumah merupakan tempat paling mudah untuk melaksanakan pertemuan Kristen. ${ }^{47}$

Penggunaan rumah bagi kekristenan mulamula juga menguntungkan untuk penerimaan sosial masyarakat di luar Kristen. Dengan menggunakan rumah sebagai tempat pertemuan, maka gereja pada masa Paulus adalah seperti pertemuan asosiasi keagamaan ketika dipandang oleh para anggota gereja, para tetangga maupun pihak berwenang setempat. ${ }^{48}$ Dengan demikian orang Kristen mulamula merasa aman untuk bertemu sebagai kelompok sosial dan terhindar dari perhatian umum. ${ }^{49}$

Dengan demikian dari seluruh uraian di atas maka gereja menggunakan struktur rumah sebagai media perwujudannya karena sudah ada dalam masyarakat sebelumnya sehingga tidak perlu membentuk lagi yang baru tetapi menggunakan bentuk yang sudah ada. Karena itu ada kemiripan dalam hal tertentu dengan kelompok sosial lain yang telah ada, khususnya dalam hal penggunaan rumah. Struktur oikos kuno diambil menjadi struktur kegiatan Kristen karena ada dalam budaya di sekitar mereka. Hal ini merupakan upaya kontekstualisasi yang cerdas karena memudahkan untuk melakukan penyebaran agama Kristen kepada orang-orang lain. Rumah menjadi basis pekerjaan misi serta menjadi pusat organisasi jemaat lokal dan pertemuan ibadah. ${ }^{50}$

Tulisan dan pekerjaan Paulus memperlihatkan hal di atas dengan lebih jelas. Paulus mengintegrasikan struktur oikos/rumah

\footnotetext{
${ }^{47}$ Robert M. Grant, Early Chrisianity and Society (London: Collins, 1978), 146.

${ }^{48}$ E. Earle Ellis, Pauline Theology: Ministry and Society (Grand Rapids: Eerdmans, 1989), 144.

${ }^{49}$ Judge. The Social Pattern, 73.

${ }^{50}$ Jurgen Becker, ed., Christian Beginnings: Word and Community from Jesus to Post-Apostolic Times (Louisville: Westminster/John Knox, 1987), 164.
}

dalam masyarakat dengan strategi misi. ${ }^{51}$ Ia menjangkau orang-orang dalam rumah mereka setelah gagal menjangkau orang di sinagoge. Dari rumah ini ia menjangkau keluarga-keluarga lainnya. Hal ini terjadi karena dunia Hellenis memang diikat oleh struktur keluarga secara menetap. ${ }^{52}$ Dengan demikian Paulus menggunakan struktur sosial yang sudah ada yang dikenali oleh orang Kristen maupun orang bukan Kristen. Paulus menggunakan secara khusus rumah tangga untuk mengorganisasi gerakan Kristen mula-mula. Dan kesuksesan misi Kristen mula-mula dan kehidupan gereja sangat terkait dengan rumah..$^{53}$

Dengan demikian Paulus telah melakukan upaya kontekstualisasi yang efektif, yaitu menggunakan struktur rumah tangga yang ada dalam masyarakat untuk menyebarkan kekristenan. ${ }^{54}$ Model Paulus ini diikuti oleh para misionaris dan pekabar Injil pada masa berikutnya. Pekabaran Injil demikian efektif sehingga dalam kurun waktu tiga abad orang

\footnotetext{
${ }^{51}$ Branick, The House Church, 18-20. Gehring, House Church, 228. Ben Witherington III, Conflict \& Community in Corinth: A Socio-Rhetorical Commentary on 1 and 2 Corinthians (Grand Rapids: Eerdmans, 1995), 30 menyebutkan bahwa di Korintus hal ini terjadi setelah penolakan di sinagoge. Dan perkumpulan Kristen bagi orang luar tampak seperti pertemuan klub sosial atau sekumpulan orang yang ingin belajar.

${ }^{52}$ Norbert Brox, A Concise History of the Early Church (Continuum International, 1995), 20.

${ }^{53}$ Eckhard J. Schnabel, Early Christian Mission: Paul and the Early Church (Downers Grove: IVP, 2004), 1301.

${ }^{54}$ Salah satu kriteria kontekstualisasi yang sehat adalah relevan bagi target misi. Lihat John Corrie, ed., Dictionary of Mission Theology: Evangelical Foundations (Nottingham, IVP, 2007), 70. Konteks penyebaran agama saat itu yang paling dikenali adalah konteks rumah dan rumah tangga. Hal ini juga yang dilakukan oleh Yudaisme dengan sinagogenya, agama mistis dengan sekte-sektenya dan bahkan sekolah filsafat-sekolah filsafat tertentu.
} 
Kristen menjadi berlipat ganda dan menjadi sangat banyak di Kerajaan Romawi. ${ }^{55}$

\section{Implikasi untuk Gereja Masa Kini}

Berikut ini akan diuraikan secara ringkas implikasi kontekstualisasi penggunaan rumah dalam upaya pekabaran Injil untuk gereja masa kini:

a. Gereja di rumah mendorong gereja masa kini untuk kembali mengembangkan gereja sebagai organisme daripada sekadar organisasi, sedikitnya menyeimbangkan keduanya. Gereja di rumah lebih memiliki suasana kekeluargaan daripada suasana formal dan struktural. Organisasi gereja haruslah lebih mementingkan hubungan dan orangorang daripada aturan dan birokrasi. Gereja mestinya menjadi tempat yang hangat di mana anggota-anggotanya dekat dan saling mengasihi dan saling menumbuhkan.

b. Gereja di rumah mendorong dikembangkannya pelayanan kelompok kecil di gereja masa kini. Tidak cukup hanya ibadah mingguan. Setiap orang percaya mesti masuk dalam kelompok kecil untuk bertumbuh melalui komunitas dan pemuridan di dalamnya.

c. Gereja di rumah mendorong upaya pekabaran Injil melalui hubunganhubungan informal selain kegiatankegiatan formal seperti ibadah dan pengajaran. Anggota-anggota jemaat

\footnotetext{
${ }^{55}$ Starks memperkirkan jumlah orang Kristen pada tahun 300 adalah lebih dari 33 juta orang dan itu lebih dari setengah populasi Kerajaan Romawi. Lihat perhitungan selengkapnya dalam Rodney Starks, The Rise of Christianity: How the Obscure, Marginal Jesus Movement became the Dominant Religious Force in the Western World in a Few Centuries. 9th print. (San Fransisco: HarperCollins, 2000), 4-7. Starks menyimpulkan tentang pertumbuhan kekristenan: "It grew because Christians constitutes an intense community. ... And the primary means of its growth was through united and motivated efforts of growing Christian believers, who invite their friends, relatives and neighbors to share the "good news". Lihat halaman 208. Hal ini sejalan dengan kontekstualisasi struktur rumah yang memungkinkan pekabaran Injil bagi jaringan sosial di sekitar rumah tangga Kristen.
}

didorong untuk menyaksikan kasih Tuhan melalui kehidupan mereka sehari-hari dan membangun hubungan dengan orang-orang sekitar mereka untuk nantinya bisa diberitakan Injil. Juga dengan terbangunnya hubunganhubungan dengan orang-orang di sekitarnya, anggota-anggota jemaat dapat mengajak mereka ke komunitas kelompok kecil atau ibadah untuk mendalami kehidupan bergereja lebih mendalam dan bertumbuh di dalam Tuhan.

Akhir kata penulis berharap melalui belajar konsep "gereja di rumah" ini gereja-gereja masa kini dapat melakukan pelayanan dalam kehidupan bergerejanya dengan pola yang lebih alkitabiah dan karenanya akan menjadi lebih efektif. 


\section{Daftar Kepustakaan}

Balz, H., Schneider, G., Exegetical Dictionary of the New Testament. Vol. 2. Grand Rapids: Eerdmans, 1991.

Banks, R. Paul's Idea of Community. Rev. ed. Peabody: Hendrickson, 1994.

Becker, J., ed. Christian Beginnings: Word and Community from Jesus to Post-Apostolic Times. Louisville: Westminster/John Knox, 1987.

Branick, V. The House Church in the Writings of Paul. Wilmington: Michael Glazier, 1989.

Bromiley, G.W., ed. The International Standard Bible Encyclopedia. 4 vols. Rev. ed. Grand Rapids: Eerdmans, 1988.

Brown, C., ed. New International Dictionary of New Testament Theology. Vol. 2. Grand Rapids: Zondervan, 1986.

Brox, N. A Concise History of the Early Church. Continuum International, 1995.

Bruce, F.F. The Epistles to the Colossians, to Philemon, and to the Ephesians. NICNT. Grand Rapids: Eerdmans, 1984.

Corrie, J., ed. Dictionary of Mission Theology: Evangelical Foundations. Nottingham, IVP, 2007.

Crosby, House of Disciples: Church, Economics \& Justice in Matthew. Maryknoll: Orbis, 1988.

deSilva, D.A. Honor, Patronage, Kinship \& Purity: Unlocking New Testament Culture. Downers Grove: IVP, 2000.

Dunn, J.D.G. Beginning from Jerusalem. Christianity in the Making Volume 2. Grand Rapids: Eerdmans, 2009.

Elliott, J. A Home for the Homeless: A Sociological Exegesis of 1Peter, Its Situation and Strategy. Philadelphia: Fortress, 1981.

Ellis, E.E. Pauline Theology: Ministry and Society. Grand Rapids: Eerdmans, 1989.

Flemming, D. Contextualization in the New Testament: Pattern for Theology and Mission. Downers Grove: IVP, 2005.

Gehring, R. House Church and Mission: The Importance of Household Structures in Early Christianity. Peabody: Hendrickson, 2004.

Grant, R.M. Early Christianity and Society. London: Collins, 1978.

Jeffers, J.S. The Graeco-Roman World of the New Testament Era: Exploring the Background of the Early Christianity. Downers Grove: IVP, 1999.

Judge, E.A. The Social Pattern of Christian Groups in the First Century. London: Tyndale, 1960.

Kittel, G., Friedrich, G., eds., Theological Dictionary of the New Testament. Vol. 5. Tr. Geoffrey W. Bromiley. Grand Rapids: Eerdmans, 1967.

Malina, B.J. "Early Christian Groups: Using Small Group Formation Theory to Explain Christian Organization," dalam Philip F. Esler, Modelling Early Christianity: Social-Scientific Studies of the New Testament in its Context. London: Routledge, 1995. 
. The New Testament World: Insight from Cultural Anthropology. Rev. ed. Louisville: Westminster/John Knox.

Meeks, W.A. The First Urban Christian: The Social World of the Apostle Paul. New Haven: Yale University Press, 1983.

Osiek, Carolyn, Margaret Y. MacDonald, dan Janet H. Tulloch. A Woman's Place: House Churches in Earliest Christianity. Minneapolis: Fortress, 2006.

Schnabel, E.J. Early Christian Mission: Paul and the Early Church. Downers Grove: IVP, 2004.

Scroggs, R. "The Earliest Christian Community as Sectarian Movement," dalam David G. Horrel, Social-scientific Approaches to New Testament Interpretation. Edinburgh: T\&T Clark, 1999.

Stambaugh, J., Balch, D., Dunia Sosial Kekristenan Mula-mula. Jakarta: BPK Gunung Mulia, 1997.

Starks, R. The Rise of Christianity: How the Obscure, Marginal Jesus Movement became the Dominant Religious Force in the Western World in a Few Centuries. 9th print. San Fransisco: HarperCollins, 2000.

von Harnack, A. The Expansion of Christianity in the First Three Century. 2 Vols. Tr. James Moffat. Eugene: Wipf \& Stock, 1998.

Witherington III, B. Conflict \& Community in Corinth: A Socio-Rhetorical Comentary on 1 and 2 Corinthians. Grand Rapids: Eerdmans, 1995. 